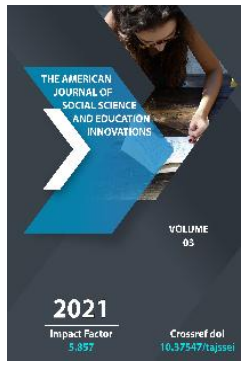

Journal Website: http://theamericanjour nals.com/index.php/taj ssei

Copyright: Original content from this work may be used under the terms of the creative commons attributes 4.0 licence.

\section{Psychological Characteristics Of Increasing Cognitive Activity In Elementary School Students}

Shohrukh Salikhov

Teacher, Department Of Psychology, Bukhara State University, Bukhara, Uzbekistan

Timur Salikhov

Teacher, Department Of Methodology And Theory Of Physical Culture, Bukhara State University, Bukhara, Uzbekistan

\title{
ABSTRACT
}

This article discusses the importance and benefits of increasing students' cognitive activity. In addition, the psychological features and methods of increasing the activity of students in the educational process are described.

\section{KEYWORDS}

Knowledge, activity, object, upbringing, education, knowledge, thinker, thinker, psychologist, feature, method experience.

\section{INTRODUCTION}

In the process of learning, as well as in the process of learning, the student goes from ignorance to knowledge, from incorrect and vague knowledge to more complete and 
precise, deeper knowledge. In this process, emotional perception is both abstract thinking and experimentation. Certain sciences and phenomena are studied in the process of knowing the objective world, and factors are identified in the process of mastering their external and internal essence. Based on observation, imagination, and abstract reasoning, facts are generalized, and theories, laws, and categories are created as a result of scientific conclusions.

Knowledge is divided into two parts - theory and practice. Theory is a systematic idea that represents new knowledge of new knowledge [1-4]. The theory is expressed in various forms; an idea is formed in an axiom, theorem, law, formula, graphic number, and other theories. Practice is a measure of the validity of knowledge. Observation, experimentation, and creation are forms of practice.

\section{MATERIALS AND METHODS}

Yusuf Khas Hajib's (1020) work "Kutadg'u bilig" ("Knowledge that brings happiness" (written in 1069)) provides information about the social and family education of the Turkic peoples, the branches of science in schools, the peculiarities of the educational system. is a source of information. According to the author, the upbringing of children should start very early, because they are prevented from indulging in inappropriate behavior. It is emphasized that for this purpose it is necessary to invite a well-intentioned and pure coach with special training. relativeity is considered. Emphasizes the importance of upbringing in the development of children's morals and good qualities. He expressed the view that some of the personal qualities in a person are innate and others are formed throughout life. Therefore, it is important to take into account the specifics of each person in the acquisition of behavior. Davoni also mentions that morality changes, develops, and improves over time [5-7]. Her teacher must be smart, knowledgeable, and goodnatured. Commenting on the relationship between the student and the teacher, the scholar said, "If the parent is the cause of the physical upbringing of the body, the teacher is the cause of the spiritual upbringing of the child." The closer a person's soul is to his body, the closer the teacher is to the student in the field of education. According to Davoni, a teacher should help a child to pursue a career in which he is interested, and support him in every way.

Hussein Waz Kashifi's pamphlet "Akhlaqi Muhsini" (1505) is devoted to moral and educational issues, which reflects the pedagogical and psychological features of the etiquette of the relationship between teacher and students. According to the thinker, in the formation of a child's morality, the influence of the external environment and the people around him is particularly strong. Under the influence of the external environment, the child not only perceives reality, but also acquires good or bad behavior. That's why Kashifi advises to be careful in raising children. The infinite role of the school and the teacher in shaping the child's worldview emphasizes that the child should be brought up by several teachers, depending on their age, rather than one teacher [8-11]. The first teacher should teach him manners, manners, modesty, honesty, humility, honesty. The second is to teach the child science, the third is to teach courage, bravery and riding, and so on. Hussein Waz Kashifi emphasizes that the teacher should be polite and fair to the 
children in the communication process. The educator must follow the rules of kindness and etiquette in teaching and educating the child. It is not good to give him a reason in public, but it is necessary to talk to a child in a secluded place. If a coach knows that the time has come to give advice, he should approach him politely, because in our time it is appropriate to be polite and kind.Ahmad Donish pays great attention to the moral image of the teacher and recognizes that he needs to work hard on himself in order to increase and deepen his knowledge in order to educate the younger generation [12-15]. According to Zakirjon Kholmuhammad oglu Furkat, the main method of education is persuasion, which should be achieved through telling, explaining and showing real-life examples. He demands that children be treated with great love and kindness, and that students be subjected to violence, intimidation, or acceptance, beatings, insults, and violence against them. condemns fluency. At school, children like to be free and happy. Abdurauf Fitrat, in The Leader of Salvation, emphasizes that children receive their first moral upbringing first of all from the family and then from those around them. According to Fitrat, children are like water, and just as water glows in a container of the same color, children also adopt any morality and habit in the same environment in which they live. Mothers and teachers themselves need to be well-mannered [16-18]. He emphasizes the importance of educating children morally in order to be a civilized nation.

Education is an activity that ensures that certain aspects of the human experience, that is, that students acquire knowledge and education in accordance with the current requirements of social development. The content of the learning process consists of knowledge, skills and competencies. This means that students are armed with knowledge through reading. Knowledge is not enough. You just have to be more discriminating with the help you render toward other people. This requires the development of skills and competencies in the teacher. A skill is a set of actions that result from an exercise. Talent and skill are developed through practice and repetition. Knowledge builds skills. Knowledge is needed in debate, skill is needed in work, in mastering the world. In this regard, it is useful to organize debates, competitions, sharp-witted, cheerful and clever, intellectual competitions among students in schools. The learning process is a two-way interaction between the teacher and the students. As a result of the teacher's work, education becomes a process based on well-thought-out goals, content, and programs, and produces the expected results. The child begins to study at an early age. She learns to read numbers and letters, learns important features of natural phenomena with the help of parents and educators, listens to stories and fairy tales, and learns to tell them to others.But the main activity of a preschooler is still play, so it is more important to feel it in his thinking activity. In the early stages of learning, students are more likely to use synthesis. Analysis is the separation of things and events into components. In the process of synthesis, students combine parts and elements of the studied objects and events into a whole. Through synthesis, analysis, comparison, and induction, students have the opportunity to develop their own understanding. The teaching process involves two activities, teacher and student. The teacher's activity is to describe the teaching materials, to stimulate students 'interest in 
science, to guide students' independent study, to test their knowledge and skills, to stimulate their interest in learning, to stimulate knowledge. The activity of the teacher is the external side of the educational process, because it teaches, teaches. Student activity is an internal process because it reads and understands the knowledge given by the teacher. The second aspect of the teaching process is the student's activity, which is to master the subject materials. Teaching, unlike learning, is done under the guidance of a teacher. The main purpose of education is to equip the younger generation with scientific knowledge, skills and abilities.Acquiring scientific knowledge means understanding the connections between certain disciplines, being able to interpret them, generalize independently, and draw conclusions. Based on this, students develop cognitive skills such as observation, thinking, memory, and faith. It is not a matter of studying all the knowledge that mankind has acquired in the process of such study. In the process of education, the most necessary and important foundations of science are studied [11-18]. To do this, the teacher, while imparting knowledge to the student, leads him from simple to complex, from general to specific, teaches him to draw conclusions, to apply them to life in production. A teacher, no matter how simple his subject, must be profoundly scientific.

In the process, the teacher explores the children's possibilities, sees their difficulties, and seeks solutions to them. A creative teacher discovers new aspects of the material, both in itself and in the way it is taught. In the same process, the teacher develops his own way.
The teacher prepares students to actively perceive new knowledge and apply it in life. This is not an accident, but the logic of the learning process. The process by which students master a lesson consists of the stages of comprehension, understanding, consolidation, and application of knowledge. The acquisition of knowledge begins with the perception and perception of things and events in reality. This stage is very important in the acquisition of knowledge. Perception is the reflection of being in the human mind, we perceive a tree, a person, an animal, and so on.

Cognition should be a goal-oriented process, depending on the level of students' knowledge and practical experience. The teacher carefully selects the sources of observation as he or she conducts the observation or direct observation. The second step in students' learning is to understand and generalize. Thoughts such as induction play an important role in the formation of concepts. Induction is a way of thinking that goes from particular to general, and deduction is from general to specific.

\section{CONCLUSION}

The third stage in students' learning is to consolidate and apply knowledge. is to strengthen the temporary connections that exist. In the process, loose and unstable connections are strengthened.

To increase student engagement, it is important to ask questions about the material during the initial consolidation. This can be done through independent work with books and textbooks, a variety of exercises, handson activities, visual aids, and computer work. 
Subsequent consolidation of the material will continue during the homework process. Repetition of material in different subsequent lessons, generalization at the end of the topic or knowledge, and repetition until the end of the school year are necessary elements of reinforcement.

One of the tools for successful acquisition of knowledge and skills is the application of previously acquired knowledge. Practice will be supplemented with knowledge and the ability to apply it in practice. Provides motivation to acquire knowledge while solving practical tasks.

\section{REFERENCES}

1. Yarashov M. (2020). Boshlang 'ich sinf matematika ta'limini ijodiy tashkil etishda ta'lim tamoyillarining o 'rni. Center for Scientific Publications. T. 1(1).

2. Jobirovich, Y. M. (2021). The Role of Digital Technologies In Reform Of The Education System. The American Journal of Social Science and Education Innovations, 3(04), 461-465.

3. Косимов, Ф. М., \& Ярашов, М. ж. (2020). Творческие самостоятельные работы на уроках математики в начальных классах. In Инновационный Потенциал Развития Науки В Современном Мире: Достижения И Инновации (рр. 178181).

4. Yunus, Y. S. (2020). Development of logical thinking in mathematics lessons as the basis for improving the quality of the educational process. 5(10). 264-267

5. Yunus, Y. S. (2021). Use of innovative technologies in improving the efficiency of primary school students. Middle European Scientific Bulletin, 11(1).

6. Yusufzoda S. (2020). O'quvchi mantiqiy tafakkurini shakllantirish omillari. Centr Nauchnyh Publikacij. 2020. T. 1(1).

7. Yunus, Y. S. (2021). Features of Logical Thinking of Junior Schoolchildren. Middle European Scientific Bulletin, 10(1).

8. Yusufzoda, S. (2019). Organization of independent work of students in mathematics. In Bridge to science: research works (pp. 209-210).

9. Yunus, Y. S. (2021). Methodology Of Teaching Assignments To Work With Non-Standard Solution In Primary School Mathematics Education. The American Journal of Social Science and Education Innovations, 3(02), 439-446.

10. Kodirova, S. A. (2020). Ideological and artistic features of «Zarbulmasal». Theoretical \& Applied Science, (10), 318-320.

11. Abdurakhimovna, K. S. Idealistic Study of Proverbs. International Journal on Integrated Education, 3(11), 201-202.

12. Саидова, Г. Э. (2019). Ситуация свободного выбора на уроках математики в начальных классах. 
Вестник науки и образования, (7-3 (61)).

13. Xoliqulovich, J. R. (2021). Toponymicsa Linguistic Phenomenon in The Work of Sadriddin Aini. Middle European Scientific Bulletin, 8.

14. Adizova, N. B. (2019). Rhyme, rhythm in fun genre. Theoretical \& Applied Science, (10), 65-67.

15. Raximqulovich, I. S. (2020). Methods of working with text in literary reading lessons in elementary school. EPRA International Journal of Multidisciplinary Research, 1, 345-347.

16. Rustamova, G. B. (2020). The interpretation of the willow image in uzbek folklore. In Лучшая Научная Статья 2020 (pp. 53-57).

17. Olloqova, M. O. (2021). Intensive education and linguistic competence in mother tongue. Academicia: an international multidisciplinary research journal, 11(1), 580-587.

18. Хамраев, А. (2018). Моделирование деятельности учителя при проектировании творческой деятельности учащихся. Педагогічні інновації: ідеї, реалії, перспективи, (2), 23-26. 